\author{
Marta LABUda \\ Uniwersytet Jagielloński \\ ORCID: https://orcid.org/0000-0002-5327-9426
}

\title{
Działalność Unii Europejskiej przeciw pandemii COVID-19 na Ukrainie'
}

\section{European Union Activity Against the COVID-19 Pandemic in Ukraine}

\section{Abstract}

The article is an attempt to look at the activity of the European Union against the COVID19 pandemic in Ukraine. The purpose of the research is to demonstrate successes and failures of the EU's activity in this area. The main research question posed in the article is: How did the EU's activity affect the course of the pandemic in Ukraine? The main research hypothesis is statement that the EU's activity has caused a significant mobilization in implementing reforms in Ukraine, but so far it has not resulted in a decrease in the number of COVID-19 cases in the country.

The research has been based on a qualitative methodology, with the document analysis strategy. The research material consisted of primary acts of the EU's institutions, government data of Ukraine and internet portals devoted to the issue. Research shows that the EU's activity against the COVID-19 pandemic in Ukraine has proved successful in terms of the need to finance actions to overcome the negative effects of it.

Keywords: COVID-19, pandemic, crisis, European Union, Ukraine

1 Artykuł powstał przy wsparciu finansowym udzielonym w ramach stypendium naukowego im. prof. Richarda Pipesa w Instytucie Studiów Politycznych Polskiej Akademii Nauk. 


\section{Деятельность Европейского Союза против пандемии Ковид-19 в Украине}

\section{Аннотачия}

Статья представляет собой попытку взглянуть на деятельность Европейского Союза против пандемии Ковид-19 в Украине. Целью исследования является презентация успехов и неудач деятельности ЕС в этой сфере. Главный исследовательский вопрос, поставленный в статье, звучит: как деятельность ЕС повлияла на ход пандемии в Украине? Основной исследовательской гипотезой является утверждение, что деятельность ЕС вызвала значительную мобилизацию для проведения реформ в Украине, но пока не привела к снижению числа случаев Ковид-19 в стране.

Исследование основано на качественной методологии со стратегией анализа документов. В исследовании были использованы документы учреждений ЕС, данные государственных органов Украины и материалы интернет-порталов. Результаты анализа показывают, что деятельность ЕС по борьбе с пандемией Ковид19 в Украине оказалась успешной с точки зрения необходимости финансирования действий по преодолению ее негативных последствий.

Ключевые слова: Ковид-19, пандемия, кризис, Европейский Союз, Украина

\section{Wprowadzenie}

Dandemia COVID-19 dała początek światowemu kryzysowi zdrowotnemu XXI wieku i jest największym wyzwaniem, przed jakim stanęło społeczeństwo od II wojny światowej. Pandemia ta okazała się czymś znacznie większym niż kryzys zdrowotny. Jest ona także bezprecedensowym kryzysem społeczno-gospodarczym.

Unia Europejska (UE) i jej państwa członkowskie ściśle współpracują i pomagają sobie nawzajem, mobilizując zasoby zapewniające zaopatrzenie w sprzęt ochronny, pobudzając badania i wspierając globalnych partnerów. UE wykorzystuje wszelkie dostępne zasoby, aby pomóc państwom członkowskim w organizowaniu reakcji na poziomie krajowym. Ponadto UE stara się także wspierać państwa stowarzyszone, a w tym Ukrainę. Wsparcie to polega na udostępnianiu obiektywnych informacji o rozprzestrzenianiu się wirusa i skutecznych metodach zapobiegania zakażeniom, a także podejmowaniu 
działań w celu naprawy szkód gospodarczych i społecznych spowodowanych pandemią.

Niniejszy artykuł jest próbą spojrzenia na działalność UE przeciw pandemii COVID-19 na Ukrainie. Z kolei celem badań jest wykazanie sukcesów i porażek działalności UE w tym zakresie. Główne pytanie badawcze postawione w niniejszym artykule brzmi: jak działalność UE wpłynęła na przebieg pandemii na Ukrainie?. W odpowiedzi na pytanie badawcze przyjęto główną hipotezę badawczą. Jest nią stwierdzenie, iż działalność UE spowodowała znaczną mobilizację we wprowadzaniu reform na Ukrainie, jednak dotąd nie poskutkowała ona spadkiem liczby zachorowań w tym kraju.

Początkowo zaprezentowano aktualny stan i przebieg pandemii na Ukrainie ze wskazaniem na skalę zachorowań. W głównej części artykułu przedstawiono konkretne kroki podjęte przez UE, mające przeciwdziałać pandemii na Ukrainie. Z kolei w dalszej części dokonano oceny działalności UE wraz z określeniem jej sukcesów i porażek.

Badania przeprowadzono w oparciu o metodologię jakościową z zastosowaniem strategii analizy dokumentów. Materiał badawczy stanowiły akty pierwotne instytucji UE oraz dane rządowe Ukrainy. Ponadto posiłkowano się portalami internetowymi poświęconymi danej problematyce.

\section{Przebieg pandemii COVID-19 na Ukrainie}

Według oficjalnych danych pandemia COVID-19 na Ukrainie rozpoczęła się później niż w innych krajach Europy. Pierwszy przypadek odnotowano dopiero 3 marca 2020 roku, podczas gdy w innych europejskich krajach liczba zachorowań przekraczała już nawet 1000. Mimo tego pandemia ta nabrała rozpędu i liczba osób zakażonych zaczęła gwałtownie wzrastać (Аналітичні панелі..., 2020).

Łączna liczba przypadków na Ukrainie według stanu na dzień 29 października 2020 roku wynosiła 370 417, z których 6868 to przypadki śmiertelne (dane te nie dotyczą okupowanych terenów w Donbasie oraz Krymu) (Ситуація в Україні..., 2020). W tym czasie wykonano 3176397 testów (o ponad 1 mln mniej niż w Polsce), około 120 tys. na milion mieszkańców, co, pomijając Albanię, jest najniższym wynikiem w Europie. Stąd wnioskować 
można, że rzeczywista skala zachorowań jest o wiele większa. Dotychczas wyzdrowiały 151632 osoby (Ситуація в Україні..., 2020).

Obecnie liczba zachorowań stale wzrasta. Dane wskazują, iż odnotowuje się około 7,5 tys. nowych przypadków na dobę (rys. 1).

Dotychczas najwięcej przypadków odnotowano w regionie charkowskim (35 016), lwowskim (28 889) i odeskim (23 623) (rys. 2).

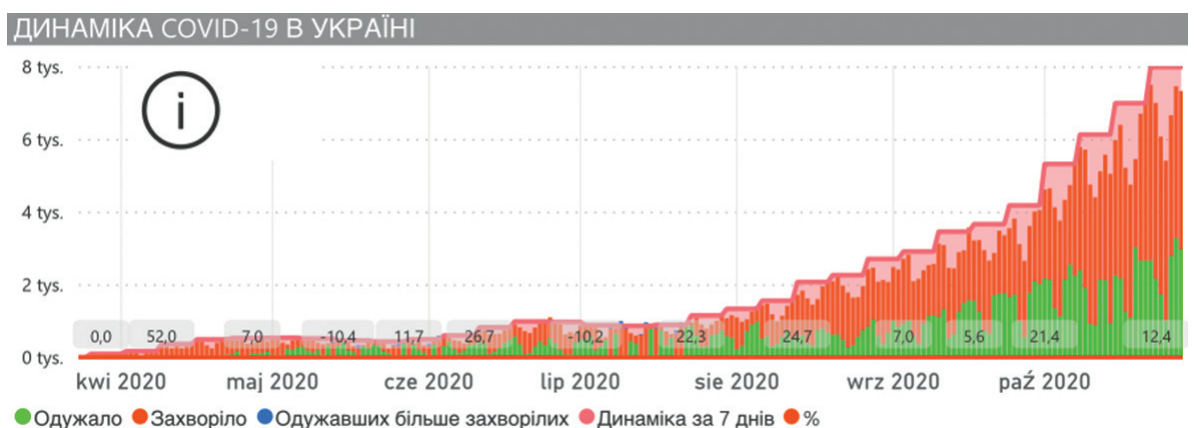

Rysunek 1. Dynamika pandemii COVID-19 na Ukrainie

Źródło: Офіційний інформаційний портал Кабінету Міністрів України. Коронавірус в Україні: (2020, 29 października). Аналітичні панелі та відкриті дані. Pobrane z: https://covid19.gov.ua/analitichni-paneli-dashbordy.

\section{ДИНАMIKA COVID-19 У РЕГIOHAX}
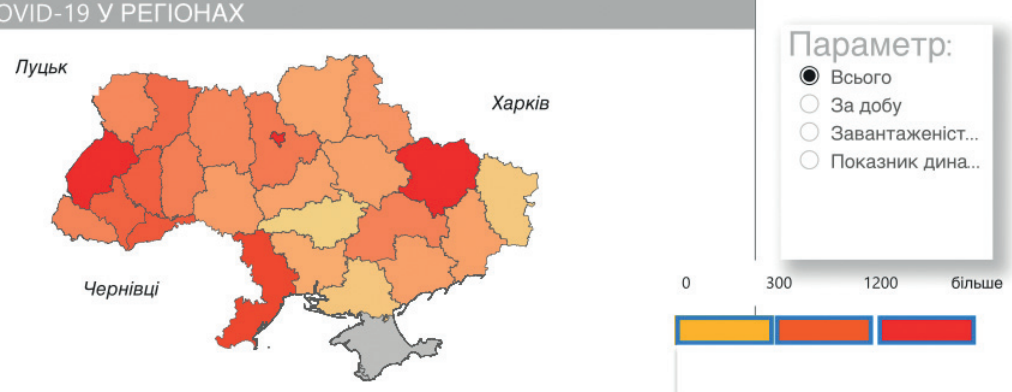

Rysunek 2. Dynamika COVID-19 w regionach Ukrainy

Źródło: Офіційний інформаційний портал Кабінету Міністрів України. Коронавірус в Україні: (2020, 29 października). Аналітичні панелі та відкриті дані. Pobrane z: https://covid19.gov.ua/analitichni-paneli-dashbordy. 


\section{Pomoc UE w przeciwdziałaniu pandemii na Ukrainie}

W dniu 8 kwietnia 2020 roku Komisja Europejska (KE) zapowiedziała około 15,6 mld EUR wsparcia dla wysiłków krajów partnerskich w walce z pandemią (Koronawirus: działania..., 2020). Wsparcie to dotyczyć miało zaspokojenia najpilniejszych potrzeb, zarówno humanitarnych, jak i w ochronie zdrowia, usprawnienia ochrony zdrowia i systemów wodno-sanitarnych, wspierania badań, a również łagodzenia skutków gospodarczych i społecznych pandemii (Koronawirus: działania..., 2020).

Działania UE od początku cechowały się podejściem tzw. „Drużyny Europy”. W celu wspierania poszczególnych krajów partnerskich połączono zasoby UE, państw członkowskich oraz unijnych instytucji finansowych, w tym Europejskiego Banku Inwestycyjnego i Europejskiego Banku Odbudowy i Rozwoju. Istotną rolę w planowaniu wsparcia dla krajów partnerskich odegrała również wypowiedź Przewodniczącej KE Ursuli von der Leyen. Przewodnicząca podkreślała, iż potrzebna jest skoordynowana globalna reakcja na pandemię, więc wsparcie partnerów będzie nieustanne (Koronawirus: działania..., 2020).

W dniu 22 kwietnia 2020 roku KE przygotowała pakiet pomocy makrofinansowej o wartości 3 mld EUR dla dziesięciu krajów partnerskich (Commission Staff..., 2020). Pakiet ten skierowany został do Republiki Albanii, Bośni i Hercegowiny, Gruzji, Jordańskiego Królestwa Haszymidzkiego, Kosowa, Republiki Mołdawii, Czarnogóry, Republiki Macedonii Północnej, Republiki Tunezyjskiej oraz Ukrainy. Środki pomocowe miały na celu ograniczenie skutków kryzysu gospodarczego związanego z pandemią. Środki winny zostać przeznaczone na reformy strukturalne mające na celu wzmocnienie zarządzania gospodarczego i przejrzystości, jak również na poprawę warunków zrównoważonego wzrostu gospodarczego (Commission Staff..., 2020).

W dniu 5 maja 2020 roku pakiet pomocy proponowany przez KE został zatwierdzony przez Radę Stałych Przedstawicieli UE. Zdecydowano, iż pomoc ta będzie udzielana $\mathrm{w}$ formie pożyczek średnio- i długoterminowych na bardzo atrakcyjnych warunkach (Proposal for a Decision..., 2020). Inicjatywę tę poparł również Parlament Europejski (PE) (Decision (EU) 2020/701 ..., 2020), w którego głosowaniu udział wzięło 687 posłów: 
547 głosowało za, 93 przeciw, a 47 wstrzymało się od głosu (Допомога вid EC..., 2020)

Z ustalonej kwoty 1,2 mld EUR pożyczek przyznano Ukrainie. Pomoc winna zostać wypłacona w dwóch transzach pożyczki (Proposal for a Decision..., 2020). Wypłatę pierwszej transzy zaplanowano na połowę 2020 roku. Uzyskanie tego preferencyjnego kredytu stało się możliwe po spełnieniu przez Ukrainę wszystkich dwunastu warunków specjalnych dla realizacji działań na rzecz reform w obszarze przeciwdziałania i walki z korupcją, polityki socjalnej, zapobiegania praniu pieniędzy, energii, realizacji polityki celnej, reformy usług podatkowych i celnych, ładu korporacyjnego w bankach państwowych, przeciwdziałania erozji podstawy opodatkowania i wycofywania zysków z opodatkowania, zmniejszenia wysokiego poziomu złych kredytów w systemie bankowym, a także uruchomienia nowego programu współpracy z Międzynarodowym Funduszem Walutowym (MFW) (Proposal for a Decision..., 2020). Druga transza winna zostać wypłacona w czwartym kwartale 2020 roku bądź w pierwszej połowie 2021 roku pod warunkiem wdrożenia kolejnych reform przez Ukrainę. Dotyczą one zwiększenia przejrzystości i efektywności zamówień medycznych, przeprowadzania reformy administracji podatkowej i celnej oraz planów reformy podatków i ceł, a także wzmocnienia niezawisłości, integralności, skutecznego funkcjonowania wymiaru sprawiedliwości. Ponadto Ukraina winna wzmocnić przejrzystość i efektywność systemu administracji publicznej oraz niezależność i efektywność pracy organów antykorupcyjnych i prokuratury, rozszerzyć uprawnienia wykonawców prywatnych, a także odzyskać aktywa ulokowane w bankach państwowych. Co więcej, Ukraina zobowiązała się także do przyjęcia w pierwszym czytaniu projektu ustawy o utworzeniu nowego organu ścigania poważnych przestępstw gospodarczych i finansowych. Dodatkowo winna ona wprowadzić ramy regulacyjne dotyczące ładu korporacyjnego przedsiębiorstw państwowych i usprawnić funkcjonowanie rynku gazu (Підиисано угоду..., 2020).

W krajach Partnerstwa Wschodniego UE uruchomiła pakiet pomocowy w sytuacjach nadzwyczajnych o wartości ponad 30 mln EUR na zaspokojenie najpilniejszych potrzeb w sektorze ochrony zdrowia. Na Ukrainę UE dostarczyła sprzęt do ratowniczego ośrodka opieki medycznej w obwodzie donieckim, obejmujący 100 zestawów środków ochrony osobistej, jak 
również ponad 70 litrów wysoce stężonego płynu antyseptycznego (Joint Communication..., 2020).

W dniu 23 czerwca 2020 roku do ukraińskiego portu lotniczego w Boryspolu (Kijów) dotarł ładunek humanitarny z UE i Światowej Organizacji Zdrowia z zapasami medycznymi o wartości ponad 1 mln EUR. Dostawa środków ochrony indywidualnej składała się z 500 tys. masek medycznych, 250 tys. fartuchów, 125 tys. masek respiratorowych, 50 tys. przyłbic ochronnych i 2,5 tys. okularów specjalnych. Miało to wystarczyć do zaspokojenia potrzeb 50 szpitali opiekujących się pacjentami z COVID-19 (Україна отримала.., 2020).

O pomoc w walce z pandemią Ukraina zwróciła się do UE za pośrednictwem Unijnego Mechanizmu Ochrony Ludności. Jedno z państw członkowskich UE - Słowacja - zaproponowało, że przekaże Ukrainie maski ochronne, środki dezynfekcyjne, koce i inne dary rzeczowe, a UE zapowiedziała zorganizowanie i dofinansowanie akcji dostarczenia tej pomocy na Ukrainę (Covid-19: European Solidarity..., 2020). 26 czerwca 2020 roku, w odpowiedzi na dodatkowe wnioski o pomoc, Polska zaproponowała przekazanie Ukrainie środków dezynfekcyjnych, masek chirurgicznych, przyłbic i innych środków ochrony osobistej. Transport i dostawę pomocy rzeczowej koordynowała i współfinansowała UE (Koronawirus: pomoc UE..., 2020).

Kolejnym ważnym wydarzeniem był 22. Szczyt UE-Ukraina - pierwszy od wybuchu pandemii niewirtualny szczyt dwustronny zorganizowany w Brukseli. UE przyznała wówczas Ukrainie kolejny pakiet wsparcia w walce ze skutkami pandemii w wysokości 190 mln EUR (Joint Statement..., 2020). Można twierdzić, iż tym samym stała się ona największym darczyńcą na rzecz Ukrainy.

Nie sposób pominąć faktu, iż KE przeznaczyła dodatkowe 10 mln EUR na pomoc humanitarną, aby wesprzeć najbardziej poszkodowanych obywateli na wschodzie Ukrainy w okresie poprzedzającym sezon zimowy, a także w odpowiedzi na rozszerzającą się pandemię. Zwiększyło to kwotę pomocy humanitarnej UE dla Wschodniej Ukrainy w 2020 roku do 23 mln EUR (European Civil Protection..., 2020). 


\section{Wnioski badawcze}

Działania rządu Ukrainy okazały się szczątkowe wobec gwałtownie wzrastającej liczby zachorowań na COVID-19. Z tego powodu Ukraina sięgnęła po pomoc UE, wnioskując o nią do Centrum Koordynacji Reagowania Kryzysowego. Na wniosek ten UE odpowiedziała konkretną ofertą.

Najpierw warto zaznaczyć, iż walkę z pandemią na Ukrainie koordynuje bezpośrednio prezydent państwa - Wołodymyr Zełeński. Z powodu braku zaufania do Gabinetu Ministrów, jak i zdolności rządu do kontroli sytuacji na szczeblu lokalnym Zełeński ambitnie dążył do tego, by działania przeciw pandemii koordynować samodzielnie. Niestety takiego ciężaru nie udało mu się udźwignąć, gdyż na Ukrainie w regionach często rządzą politycy opozycyjni. Ci w początkowym stadium pandemii wprowadzali własne regulacje, niezależne od zaleceń władz centralnych. Przykładem takich zachowań jest oświadczenie burmistrza Charkowa Hennadija Kernesa z 16 marca 2020 roku o tym, że nie zastosuje się do rozporządzenia prezydenta о zamknięciu metra na czas kwarantanny (Кернес відмовився..., 2020). Podobne sytuacje zmusiły Zełeńskiego do szukania pomocy u oligarchów i przedstawicieli biznesu. Prezydent poprosił ich, by objęli kontrolę nad regionalnymi sztabami antykryzysowymi, finansując np. zakup sprzętu medycznego. W ten sposób - dzięki znajomości Ołeksandra Jarosławskiego z chińskim miliarderem Jackiem Ma - Ukraina uzyskała sprzęt medyczny z Chin (Джек Ма і Ярославський..., 2020). Ponadto na dalszą walkę z pandemią Jarosławski przeznaczył kolejne $3 \mathrm{mln}$ USD (Ярославський дав \$3 млн..., 2020). Co więcej, na zwalczanie pandemii negatywnie wpłynęło mało zdyscyplinowane społeczeństwo, które początkowo całkowicie nie przestrzegało wprowadzanych reguł. Równie poważną barierą była zła sytuacja ukraińskiej służby zdrowia. Korupcja, zaniedbane szpitale, brak sprzętu medycznego i środków ochrony osobistej były powodem braku zaufania obywateli do systemu opieki zdrowotnej. Potwierdzeniem tego jest ostatni The Global Health Security Index, w którym Ukraina uplasowała się na 94. miejscu z 195 krajów (2019 Global Health Security Index..., 2019). Wszystko to przełożyło się na pogorszenie się gospodarki ukraińskiej i jednoznacznie potwierdziło, iż Ukraina nie zwalczy pandemii bez pomocy z zewnątrz. 
Perspektywy recesji gospodarczej skłoniły ukraiński rząd do negocjacji z MFW w sprawie nowego kredytu w wysokości 8 mld USD. Rząd ten przyjął ustawę liberalizującą obrót ziemią rolną (Закон України..., 2020) oraz - w drugim czytaniu - ustawę mającą uniemożliwić zwrot poprzednim właścicielom (najczęściej oligarchom) banków znacjonalizowanych po 2014 roku w związku z ich niewypłacalnością (Закон України..., 2020). Przyjęcie tych ustaw było warunkiem uzyskania pomocy od MFW (MFW oczekuje..., 2020), a współpraca z MFW - warunkiem dalszej pomocy UE.

Oprócz pomocy od MFW Ukraina wciąż oczekuje na realizację wsparcia zaproponowanego przez UE - na wcześniej przedstawiony pakiet wsparcia w wysokości 190 mln euro, jak i na częściowo zrealizowany pakiet pomocowy w wysokości 1,2 mld EUR. W tym zakresie ukraiński rząd również poczynił postępy - pierwsza transza pakietu pomocowego w wysokości 1,2 mld EUR została wypłacona. Z kolei druga transza tego pakietu, stanowiąca 600 mln EUR, zostanie wypłacona po wprowadzeniu przez Ukrainę kolejnych reform. W rozmowie z dziennikarzami w Brukseli premier Denys Szmyhal zasugerował, że reformy winny zostać wprowadzone na początku 2021 roku. UE jest natomiast jeszcze bardziej optymistyczna i uważa, że Ukraina może sprostać wymaganiom do końca 2020 roku (UE przyznała Ukrainie..., 2020).

W związku z powyższym wywnioskować można, iż działania UE, jej instytucji i państw członkowskich, są na tyle istotne dla władz ukraińskich, że są one w stanie zmobilizować się w krótkim czasie i dokonać tego, czego już od dawna od nich się oczekiwało. Można jednoznacznie stwierdzić, iż działania podjęte przez UE, jej instytucje i konkretne państwa członkowskie, stanowią dużą pomoc dla Ukrainy w walce z pandemią.

Analizując działalność UE przeciw pandemii COVID-19 na Ukrainie należy stwierdzić, iż największym sukcesem było połączenie zasobów UE, państw członkowskich oraz unijnych instytucji finansowych, takich jak Europejski Bank Inwestycyjny i Europejski Bank Odbudowy i Rozwoju. Przełożyło się to z pewnością na wysokość wsparcia finansowego nie tylko dla Ukrainy, ale także dla innych państw stowarzyszonych. Za kolejny sukces działalności UE uznano sposób wypłacania środków w ramach pakietów pomocowych. Jednoznacznie dobrym podejściem jest podział pakietów pomocowych na transze oraz łączenie wymaganych warunków ze współpracą z innymi instytucjami (np. MFW). Dzięki takim działaniom UE rząd Ukrainy 
znacznie szybciej się mobilizuje do wprowadzania reform - i nie tylko tych wymaganych do uzyskania wsparcia finansowego, a też tych zawartych w umowie stowarzyszeniowej z UE.

Jedyną porażką UE w przeciwdziałaniu pandemii na Ukrainie jest sprawowanie jednak dość ograniczonej kontroli nad tym, w jaki sposób środki przyznawane Ukrainie są rozdysponowane przez władze. W tej kwestii należy pamiętać, iż Ukraina w dalszym ciągu pozostaje państwem z wysokim wskaźnikiem korupcyjności. Dlatego też UE powinna wdrożyć dodatkowy mechanizm kontrolny w zakresie przestrzegania właściwego wykorzystywania uzyskiwanych przez Ukrainę środków finansowych. Co więcej, niekiedy bardziej wskazane byłoby wsparcie o charakterze niefinansowym - np. odbudowa szpitali czy dostawa respitarorów.

\section{Zakończenie}

W niniejszym artykule podjęto próbę oceny działalności UE przeciw pandemii COVID-19 na Ukrainie. Celem badań było wykazanie sukcesów i porażek działalności UE w tym zakresie. Przeprowadzone badania wykazały, iż do sukcesów zaliczyć należy połączenie zasobów UE, państw członkowskich i innych unijnych instytucji finansowych oraz sposób wypłacania środków w ramach pakietów pomocowych. Do porażek natomiast zaliczyć można dość ograniczoną kontrolę w zakresie przestrzegania właściwego wykorzystywania otrzymywanych środków finansowych przez władze ukraińskie.

Głównym pytaniem badawczym niniejszego artykułu było: jak działalność UE wpłynęła na przebieg pandemii na Ukrainie?. Z kolei główną hipotezą badawczą było stwierdzenie, iż działalność UE spowodowała znaczną mobilizację we wprowadzaniu reform na Ukrainie, jednak dotąd nie poskutkowała ona spadkiem liczby zachorowań w tym kraju. Przeprowadzone w oparciu o akty pierwotne instytucji UE oraz dane rządowe Ukrainy badania pozwoliły na potwierdzenie tak sformułowanej hipotezy.

Konkludując, działalność UE przeciw pandemii COVID-19 na Ukrainie okazała się sukcesem z punktu widzenia potrzeby finansowania działań na rzecz przezwyciężenia negatywnych skutków pandemii. Pomimo iż krzywa zachorowań na COVID-19 charakteryzuje się wciąż tendencją rosnącą, pozyskanie wszystkich przedstawionych w niniejszym artykule form pomocy UE 
przyczynić się powinno do utrzymania stabilności finansowej na Ukrainie. Niemniej jednak w związku ze złą sytuacją w służbie zdrowia i nieskoordynowanym zarządzaniem kryzysem, pandemia na Ukrainie może trwać dłużej niż w innych krajach Europy.

\section{MGR MARTA LABUDA}

Katedra Studiów nad Procesami Integracyjnymi

Instytut Nauk Politycznych i Stosunków Międzynarodowych

Wydział Studiów Międzynarodowych i Politycznych

Uniwersytet Jagielloński

ul. Władysława Reymonta 4, 30-059 Kraków

marta.labuda@doctoral.uj.edu.pl

\section{Bibliografia}

Council of the EU. (2020, 6 października). Joint Statement following the 22nd EU-Ukraine Summit. 6 October 2020. Pobrane z: https://www.consilium. europa.eu/pl/press/press-releases/2020/10/06/joint-statement-following-the22nd-eu-ukraine-summit-6-octobre-2020/pdf.

European Commission. (2020, 22 kwietnia). Commission Staff Working Document on providing Macro-Financial Assistance to enlargement and neighbourhood partners in the context of the Covid-19 pandemic crisis. Accompanying the document. Proposal for a Decision of the European Parliament and of the Council on providing Macro-Financial Assistance to enlargement and neighbourhood partners in the context of the Covid-19 pandemic crisis. SWD/2020/63 final. Pobrane z: https://eur-lex.europa.eu/ legal-content/EN/TXT/PDF/?uri=CELEX:52020SC0063\&from=EN.

European Commission. (2020, 24 kwietnia). Proposal for a Decision of the European Parliament and of the Council on providing Macro-Financial Assistance to enlargement and neighbourhood partners in the context of the Covid-19 pandemic crisis, COM/2020/163 final. Pobrane z: https://eur-lex.europa.eu/legal-content/EN/TXT/ $\mathrm{PDF} /$ ?uri=CELEX:52020PC0163\&from=EN.

European Commission. (2020, 26 czerwca). Covid-19: European Solidarity in action. Pobrane z: https://ec.europa.eu/commission/presscorner/detail/pl/FS_20_563.

European Commission. (2020, 6 października). European Civil Protection and Humanitarian Aid Operations, Ukraine. Pobrane z: https://ec.europa.eu/echo/where/europe/ ukraine_en.

European Commission. (2020, 8 kwietnia). Joint Communication to the European Parliament, the Council, the Economic and Social Committee and the Committee of the Regions. Communication on the Global EU response to Covid-19. 
JOIN/2020/11 final. Pobrane z: https://eur-lex.europa.eu/legal-content/EN/TXT/ $\mathrm{PDF} /$ ?uri=CELEX:52020JC0011\&from $=$ PL.

Global Health Security Index. (2019). 2019 Global Health Security Index. Ukraine. Pobrane z: https://www.ghsindex.org.

Komisja Europejska. (2020, 8 kwietnia). Koronawirus: działania podejmowane przez UE na świecie $w$ walce $z$ pandemią. Pobrane z: https://ec.europa.eu/commission/ presscorner/detail/pl/ip_20_604.

Komisja Europejska. Przedstawicielstwo w Polsce. (2020, 18 maja). Koronawirus: pomoc UE dla Ukrainy. Pobrane z: https://ec.europa.eu/poland/news/200518_ukraine_pl.

LB.ua. (2020, 16 marca). Кернес відмовився закривати метро Харкова через коронавірус. Pobrane z: https://lb.ua/news/2020/03/16/452703_kernes_otkazalsya_zakrivat_metro.html.

LB.ua. (2020, 17 marca). Ярославський дав \$3 млн на боротьбу з коронавірусом, Pobrane z: https://lb.ua/news/2020/03/17/452804_yaroslavskiy_dal_3_mln_borbu. html.

Mind. (2020, 16 marca). Джек Ма і Ярославський профінансували закупівлю експрес-тестів для України. Pobrane z: https://mind.ua/news/20208796-dzhek-ma-i-yaroslavskij-profinansuvali-zakupivlyu-eksprestestiv-dlya-ukrayini.

Official Journal of the European Union. (2020, 25 maja). Decision (EU) 2020/701 of the European Parliament and of the Council of 25 May 2020 on providing macro-financial assistance to enlargement and neighbourhood partners in the context of the Covid-19 pandemic. Pobrane z: https://eurlex.europa.eu/legal-content/EN/TXT/ $\mathrm{PDF} /$ ? uri=CELEX:32020D0701\&from=EN.

Ukrinform. Multijęzykowa medialna platforma Ukrainy. (2020, 6 kwietnia). MFW oczekuje, że Ukraina przyjmie ustawę bankowa i zmiany do budżetu. Pobrane z: https:// www.ukrinform.pl/rubric-economy/2912875-mfw-oczekuje-ze-ukraina-przyjmie-ustawe-bankowa-i-zmiany-do-budzetu.html.

WEEC. (2020, 24 lipca). UE przyznała Ukrainie 1,2 mld euro kredytu, ale „najpierw reformy". Pobrane z: https://studium.uw.edu.pl/ue-przyznala-ukrainie -12-mld-euro-kredytu-ale-najpierw-reformy/.

Верховна Рада України. (2020,31 marca). Закон України про внесення змін до деяких законодавчих актів України щодо умов обігу земель сільськогосподарського призначення. Pobrane z: https://zakon.rada.gov.ua/laws/show/552-20\#Text.

Верховна Рада України. (2020, 13 таја). Закон Украӥни про внесення змін до деяких законодавчих актів України щодо удосконалення механізмів регулювання банківської діяльності. Pobrane z: https://zakon.rada.gov.ua/laws/ show/590-20\#Text.

Євроінтеграційний портал. (2020, 23 czerwca). Україна отримала від ЄС і ВООЗ близько мільйона одиниць медичних засобів для боротьби з коронавірусом. Pobrane z: http://eu-ua.org/novyny/ukrayina-otrymala-vid-yes-i-vooz-blyzko-milyona-odynyc-medychnyh-zasobiv-dlyaborotby-z.

Міністерство Охорони Здоров’я України. (2020, marzec). Оперативна інформачія про потирення коронавірусної інфекиії 2019-nCoV. Pobrane z: https://moz. gov.ua/article/news/operativna-informacija-pro-poshirennja-koronavirusnoi -infekcii-2019-ncov-. 
Офіційний інформаційний портал Кабінету Міністрів України. Коронавірус в Україні. (2020,29 października). Аналітичні панелі та відкриті дані, Pobrane z: https://covid19.gov.ua/analitichni-paneli-dashbordy.

Офіційний інформаційний портал Кабінету Міністрів України. Коронавірус в Україні. (2020, 29 października). Ситуація в Україні. Pobrane z: https://covid19. gov.ua/.

УкрІнформ. Мультимедійна платформа іномовлення України. (2020, 25 sierpnia). Допомога від ЄС: Урядовий портал. Єдиний веб-портал органів виконавчої влади України. Департамент комунікацій Секретаріату Кабінету Міністрів України. (2020, 23 liрса). Підписано угоду щодо отримання 1,2 млрд євро макрофінансової допомоги від ЄC. Pobrane z: https://www.kmu.gov.ua/news/ uryad-pidpisav-ugodu-shchodo-otrimannya-12-mlrd-yevro-makrofinansovoyi-dopomogi-vid-yes.

Рада ратифікувала меморандум і кредитну угоду. Pobrane z: https://www.ukrinform. ua/rubric-economy/3087010-dopomoga-vid-es-rada-ratifikuvala-memorandum-i-kreditnu-ugodu.html. 